\title{
Memory of Imagination - Reflections of PQ 2019
}

\author{
Markéta Fantová \\ PQ 2019 Artistic Director, Prague, Czech Republic \\ E-mail: marketa.fantova@gmail.com
}

\section{Abstract}

The face of the Prague Quadrennial (PQ) has been slowly changing from the traditional gallery style presentation with national competitions toward an immersive experiential event, a festival. But the key question and the main mission of $P Q$ is still the same: finding engaging ways to present and exhibit performance design/scenography. As the curator of the PQ 2019 and also for the next event that will happen in 2023, I present in this brief essay the changings that have been happening along the years, and not only by one curatorship but by a team of curators that work to discuss the artistic vision, where we collaboratively developed an overall concept for all projects of the festival - an example of the teamwork we sought in our exhibitions and performances.

Curator. Curatorship. PQ 2019. Prague Quadrennial.
O rosto da Quadrienal de Praga (PQ) tem mudado lentamente de um estilo de apresentação tradicional, com competições nacionais expostas em uma galeria, para um evento experimental imersivo, um festival. Mas a questão-chave e a principal missão da $P Q$ ainda é a mesma: encontrar maneiras interessantes de apresentar e exibir design da performance/cenografia. Como curadora da PQ 2019 e também do próximo evento que acontecerá em 2023, apresento neste breve ensaio as mudanças que vêm ocorrendo ao longo dos anos, e não apenas por uma curadoria, mas por uma equipe de curadores que trabalha para discutir a visão artística, em que desenvolvemos colaborativamente um conceito geral para todos os projetos do festival - um exemplo do trabalho em equipe que buscávamos em nossas exposições e performances.

\section{Curador. Curadoria. PQ 2019.}

Quadrienal de Praga. 
Prague Quadrennial means to many a twoweek scenography event taking place every four years since 1967 in Prague, Czech Republic. We are trying to change this perception and present $P Q$ as a continual stream of activities and collaborations happening across the globe with many different partners, creatives, disruptors, artists, researchers and theorists. We keep the door open for our performing arts collaborators to stay involved in many different ways, to participate and contribute to the performance design community. $P Q$ is shedding its "every four year scenography Olympics" status and no longer starts with the opening ceremony and ends with the last visitor leaving the exhibition grounds. Our current philosophy reflects an ongoing creative cradle-to-cradle process and an attempt to map the evolution of performance design, scenography and performance space though a series of many different events, such as the Project EMERGENCE, the PQ Studio... culminating in the Quadrennial Festival and Exhibition. The cyclical nature of the creative process specific to performance design was reflected in the last edition's theme: Imagination, Transformation and Memory.

The key question and the main mission of $P Q$ is still the same: finding engaging ways to present and exhibit performance design/scenography. The solutions keep evolving. The face of $P Q$ has been slowly changing from the traditional gallery style presentation with national competition toward an immersive experiential event. The main objective of the $P Q$ exhibitions of the past century was an exhibition of scenography artifacts and fragments that, similarly to pieces of our past seen through the lens of archeology, didn't tell the full story. This style of presentation allowed the viewer to catch a glimpse of the scenographer's mind, way of thinking and scenographic dramaturgy revealed through sketches of dramatic situations. Sketches, models, notes and the rest of the scenography fragments are important, but we learn very little about the emotions and thoughts of the audiences and the overall atmosphere of the performance.

Performance design/scenography of today is often presented through live immersive experiences where all senses can be involved and the viewer takes on an active role. The most recent $P Q$ presented scenography as an experiential and sensorial realm with a focus on the creative collaboration that stands behind new ideas and experimental work. We see contemporary performance design as an art form that devises visual and sensorial parameters of new experiences.

None of this happened fast or as one curatorial decision, but was a part of a gradual development starting prior to $P Q$ 2003. As $P Q$ grew and new countries and regions joined and participated in a variety of activities, the diversity of views and ideas grew also. This was and still is an exciting development that requires more open rather than strict curatorial guidelines, especially if we are trying to map new trends in performance design worldwide.

Incredible performance designs come from a vast variety of spaces, traditional theatres, found spaces, adapted sites, public spaces, private apartments with audiences watching, actively participating, and/or drawn by disruption in a public space. Scenography happens in every corner of our inhabited world, and the PQ 2019 Exhibition of Countries and Regions, Student Exhibition and the Exhibition of Performance Space all reflected the colorful mosaic of diverse creative approaches

The curiosity to see new developments led us to consciously avoid parameters built on western cultural conventions and push for a more inclusive concept for all exhibitions and festival events. Our main goal was to empower local uniqueness as an important source of inspiration. Unique ideas and innovation based on local resources were the main driving forces behind the festival performances, workshops and $\mathrm{PQ}$ Studio events.

The team of curators met in London in 2017 to discuss the artistic vision, where we collaboratively developed an overall concept for all projects of the festival and, from there, the curatorial team became an example of the teamwork we sought in our exhibitions and performances. It was clear to us that this current world no longer supports stand-alone scenographers who act as single authors and are 
considered beacons of inspiration. We entered a period where strong teams of collaborators can better navigate the complex world of less and less centrally supported culture by sharing and inspiring each other.

The artistic vision of 2019 PQ festival projects was written with all generations of professionals in mind, keeping one foot in the past and an eye in the future. It would be impossible to map a landscape of performance design without having a sample of the works of scenography legends, whose work became the foundation for new contemporary performance design trends. For the $P Q 2019$, we decided to show a sample of work of many legends in one shared space putting their work into direct dialogue. The project, called Fragments and curated by Klara Zieglerova, was purposely based on traditional exhibition practice to reveal the thinking process and the most important ideas of the past. $36 Q^{\circ}$, on the other hand, was our way of questioning the future and the role of technology in the performing arts. $36 \mathrm{Q}^{\circ}$ was a complex collaboration between performance designers, visual artists, new media artists, and technology partners. The production of the $36 Q^{\circ}$ space was a process of strong teamwork where Jan K. Rolnik and I shared the curation, but worked in very close collaboration with the $36 \mathrm{Q}^{\circ}$ team and 95 participating artists sharing responsibilities seamlessly. The result was an immersive landscape reaching from a fully sensorial experience into a fantastic virtual extension of the existing space.

To underline the fact that many performances are taking place outside of theatre buildings, we brought attention to site as a place where audience and performers have an opportunity to rewrite the way they interact. Site Specific Performance Festival was a project bringing into focus the genius loci of a site. Site affects every type of performance design/ scenography. Every place or building, including theatre buildings, has its own atmosphere and structure, which become part of the overall design. The projects selected by the curator Sophie Jump covered a wide spectrum of site specific and site adaptive approaches from aerial dance on the sidewall of the main $P Q$ hotel Mamashelter - iconic architecture of 1960's Prague - to the archeological building of the past PQ's exhibitions, where the first PQ took place in 1967. And since site inspires performance design work, it was also undeniably the site of PQ 2019, The Prague Exhibition Grounds, which inspired a project called Formations. Movement as an element defining scenic space was at the very start of the idea developed into its final format by two curators: choreographer D. Chase Angier and architect Serge Von Arx. Curators not only called on the artists to define space by movement, but to also share the space and create unexpected interactions employing chance as an important artistic element.

Some of the mentioned projects were specific to $P Q 2019$, but there are also ongoing projects that transcend the end of each $P Q$ and continue its activities. PQ Studio, which during the PQ Festival became a hub for all interested in learning, is continuing its activity led by the curator Patrick Du Wors, albeit at the moment sadly virtually, since we are all pushed into isolation by the Corona virus. PQ Studio evolved into its own format from the student-geared project Scenofest. Scenofest was created in cooperation between PQ and OISTAT organization, devised by Pamela Howard and Michael Ramsaur, and further evolved into World Stage Design educational project. Similarly, $P Q$ continued its own student project called PQ Lab in 2015 that has now become an ongoing educational platform: PQ Studio. PQ studio offers workshops, residencies and performance opportunities for emerging artists. During PQ 2019, the $P Q$ Studio educational festival was based at and around the Theatre Academy and couldn't have happened without support from DAMU production students led by Michal Lázňovský who, together with Patrick, curated the festival performance selection.

Another continuing project is $P Q$ Talks led by Barbora Příhodová and Pavel Drábek. This ongoing discussion forum is an anchor collecting the most interesting ideas, thoughts and theories from performance design, architecture, performing arts education and research. 
The spirit of sharing and interest in participation was overwhelming for all curators and in all projects of the PQ 2019.

The recognition that $P Q$ scenography/performance design center of gravity is continuously moving away from the traditional western style performing arts model, where there are clear roles for performers and spectators, opened a vast field of possibilities and diminished the clearly labeled boxes for each performance design profession. We are still going through this transformation both artistically and organizationally. It brings on new exciting ideas, multidisciplinary collaborations, more active involvement for creative teams and audiences alike as well as a more complex and diverse landscape for curators to navigate. We might be experiencing an era of significant shifts, which is both scary and exciting, invigorating and inspiring and, as artists, we will always find a way to share our work with communities across borders and in difficult times such as this current pandemic.

Recebido: 26/03/2020

Aprovado: 21/06/2020

This is an open-access article distributed under the terms of the Creative Commons Attribution License 4.0 International. Available at: <http://creative commons.org/licenses/by/4.0>. 